\title{
The Effect of Horizontal Vulnerability on the Stiffness Level of Reinforced Concrete Structure on High-Rise Buildings
}

\author{
Fanny Monika ${ }^{1}$, Berkat Cipta Zega ${ }^{2}$, Hakas Prayuda ${ }^{1, *}$,Martyana Dwi Cahyati ${ }^{1}$, Yanuar Ade \\ Putra ${ }^{1}$ \\ ${ }^{1}$ Department of Civil Engineering, Faculty of Engineering, Universitas Muhammadiyah Yogyakarta, INDONESIA \\ ${ }^{2}$ Department of Civil Engineering, Faculty of Engineering, Universitas Negeri Surabaya, INDONESIA \\ *Corresponding authors: hakasprayuda@umy.ac.id
}

SUBMITTED 28 October 2019 REVISED 29 November 2019 ACCEPTED 23 January 2020

\begin{abstract}
Buildings have an essential function; they are a place for people to carry out various activities, such as social, economic, and religious activities. In a building construction plan, considering multiple factors from strength to architecture is necessary. The issue of limited land in some areas has resulted in the construction of vertical buildings, often known as high-rise buildings. High-rise building construction requires paying attention to various levels of vulnerabilities, especially for projects in earthquake-prone areas. In this study, the levels of vulnerability and vertical irregularity of high-rise buildings were analyzed based on structural rigidity for reinforced concrete structures. Building models including a cube-shaped model, L-shaped model, and U-shaped model were investigated. The STERA 3D program was used to determine the strength values of the structures by providing earthquake loads on each structure model using the time-history analysis method. The El Centro and Kobe earthquakes were tested in these structural models because the earthquakes are known to contribute the most exceptional damage value in the history of earthquake-caused disasters. The assessed parameters of the tested structural models include structural stiffness, the most significant displacement in the structure, the maximum displacement and load relations experienced by the construction, and the hysteretic energy exhibited by the structure. Therefore, the best performed structural model in resisting the load could be obtained. The results showed that the U-shaped building model had the highest stiffness value with an increase in stiffness of $7.43 \%$ compared with the cube-shaped building model and $3.01 \%$ compared with the L-shaped building model.
\end{abstract}

KEYWORDS High-rise Building; Horizontal Vulnerability; Stiffness; STERA 3D; Time history

(c) The Author(s) 2018. This article is distributed under a Creative Commons Attribution-Share Alike 4.0 International license.

\section{INTRODUCTION}

Buildings are essential because they support the function of various human activities, such as economic, social, and housing activities. According to FEMA-426 (2011), the architecture of Buildings and Infrastructure Protection can be divided into several main groups based on the layout, and buildings can be grouped into several forms so that the strength of structures with variations in horizontal cross section can be studied. The horizontal system includes horizontal stiffeners (commonly called horizontal diaphragms) in the form of the story and deck framing systems (Majore, 2015).

According to Weningtyas (2017), beam-column joints in precast concrete are used to determine the values of elasticity, energy dissipation, stiffness, strain stress, and crack patterns based on variations in column dimensions to assess the strength of the structure due to the forces gradually acting on each dimensional change. The existence of effects that occur at these levels will result in displacement and deviation (Cornelis and Umbu, 2014).

One of the essential requirements in constructing an earthquake-resistant building is knowing the peak ground acceleration by determining the highest acceleration value produced by an earthquake on the surface of a particular area and at a particular time (Massinai et al., 2016). Kapojos et al. (2015) stated that in earthquakeresistant buildings, the ground velocity value could be calculated using earthquake time- 
history data. Saito (2016) investigated the characteristics of high-level buildings under long-period ground motion using a 37-story building simulation and the STERA 3D software by analyzing the time history of the structure.

The behavior of reinforced concrete structures has been studied by several researchers, including Louzai and Abed (2014), who researched the behavior of multilevel reinforced concrete structures, considering three-, seven-, and ninestory buildings. The results for the dynamic incremental analysis method showed that the seismic behavior factor was 2.32 for the threestory building, 2.43 for the seven-story building, and 2.48 for the nine-story building. Meanwhile, Pavel (2018) studied reinforced concrete that was designed in seismic conditions considering 5 - to 11-story buildings. The results showed that the building collapse rate for the four structural models analyzed was in the range of $4 \times 10^{-4}$ to $4 \times 10^{-5} \mathrm{~cm}$.

Li et al. (2016) researched the optimization of high-rise buildings at collapsing capacity for seismic designs. The results showed that the reduction in the building collapse reached the range of $23.75 \%-44.18 \%$ for reinforced concrete structure building framework of 4 to 10 stories. Brunesi et al. (2016) conducted a seismic analysis in high-level repetitive buildings with the addition of mega-cores. The results showed peak displacement in the highest cases of $0.77 \mathrm{~m}$ and $1.83 \mathrm{~m}$. Lu et al. (2015) investigated shear wall elements by non-linear analysis in high-rise buildings. The displacement experienced by the peak of the structure was found to be $1,791 \mathrm{~m}$ for the $\mathrm{X}$-direction and $1,580 \mathrm{~m}$ for the $\mathrm{Y}$-direction.

In this study, three types of building construction plan variations, namely cube-shaped, L-shaped, and U-shaped building models, were analyzed, with each building having a height of $60 \mathrm{~m}$ and the same area. The levels of stiffness and displacement were measured using earthquake time-history records from the El Centro and Kobe earthquakes. This study aims to compare the results of stiffness and displacement from the variations of high-rise buildings that have been subjected to the same type of earthquake. It is expected that this research can provide information about the level of building vulnerability due to the irregularity of the building construction plan used.

\section{METHODS}

\subsection{Building Information}

This study used three building models that vary in horizontal planes, namely a cube-shaped model, L-shaped model, and U-shaped model. The building has 12 stories and a total height of $60 \mathrm{~m}$. Table 1 presents the general data of each building model. Meanwhile, Figure 1 shows the beam cross section and column cross section, which have the same size. By using the STERA application, only a small amount of material data is required to facilitate the modeling process. The building data used are general data that have been previously surveyed.

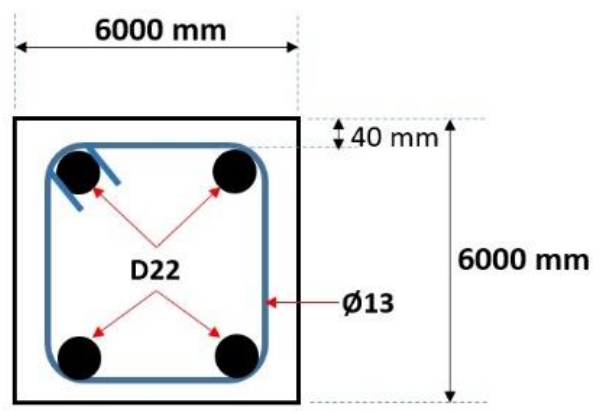

Figure 1. Beam cross section and column cross section

Table 1. Data structure model

\begin{tabular}{llll}
\hline Building Description & \multicolumn{2}{l}{ Dimensions of Structure Models } \\
& Cube-shaped Model & L-shaped Model & U-shaped Model \\
\hline The number of stories & 12 stories & 12 stories & 12 stories \\
Total building height & $60 \mathrm{~m}$ & $60 \mathrm{~m}$ & $60 \mathrm{~m}$ \\
Story height & $5 \mathrm{~m}$ & $5 \mathrm{~m}$ & $5 \mathrm{~m}$ \\
Total building width & $20 \mathrm{~m}$ & $25 \mathrm{~m}$ & $30 \mathrm{~m}$ \\
Total building length & $20 \mathrm{~m}$ & $25 \mathrm{~m}$ & $15 \mathrm{~m}$ \\
Total building area & $400 \mathrm{~m} 2$ & $400 \mathrm{~m} 2$ & $400 \mathrm{~m} 2$ \\
\hline
\end{tabular}




\subsection{Structure Modeling}

Figure 2 depicts the building dimensions used. Different building dimensions were used in this study, but the total building areas of the three variations were the same. The test was conducted by modeling; this method can allow a comparison for each test. The structure was modeled with an open structure frame system with force derived from the structure's weight and earthquake. The program used in this study is STERA 3D v9.6.

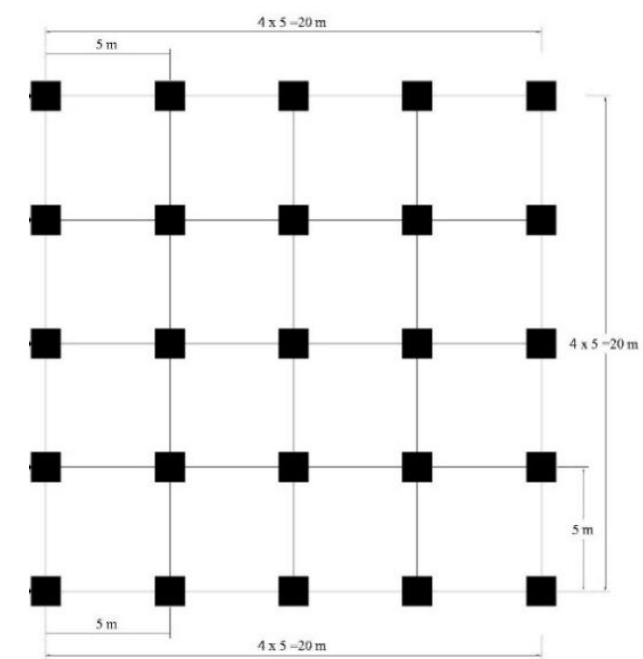

(a)

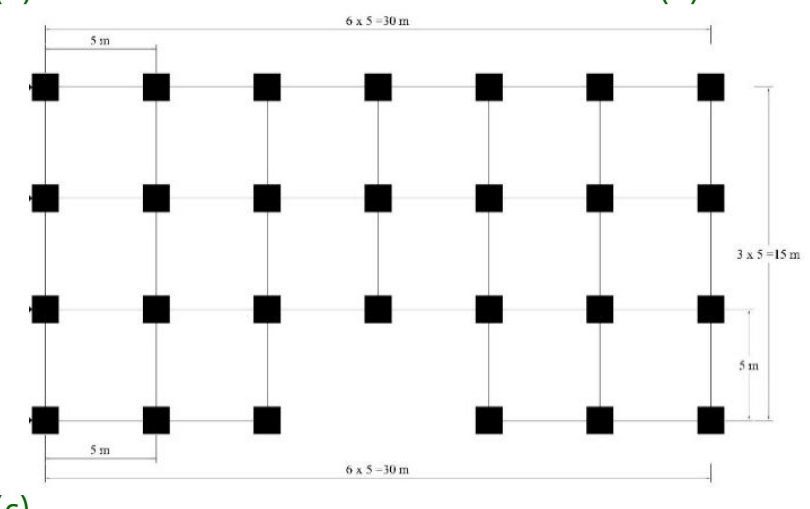

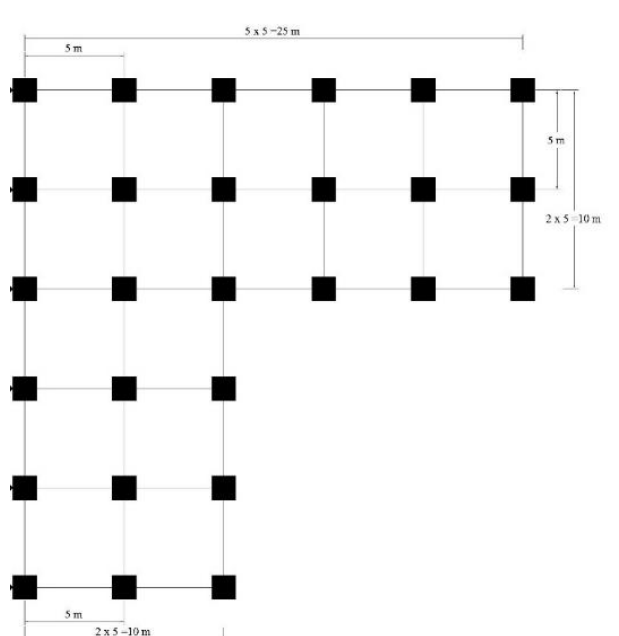

(b)

Figure 2. Blueprints of (a) cube-shaped model; (b) L-shaped model; (c) U-shaped model

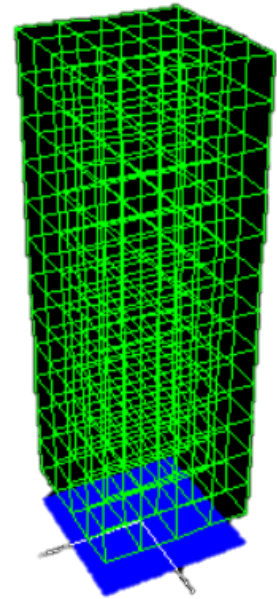

(a)

(b)

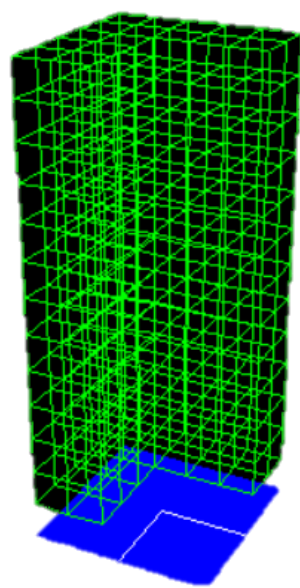

(c)

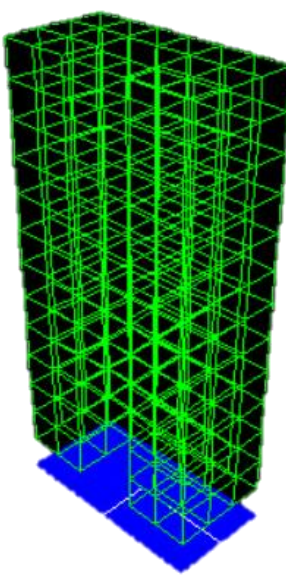

)

Figure 3. Three-dimensional diagrams of (a) cube-shaped model; (b) L-shaped model; (c) U-shaped model 
The earthquake speed was estimated using data from the El Centro earthquake in 1940 and Kobe in 2015 because it is the largest earthquake that has ever occurred. Figure 3 depicts threedimensional views taken from the STERA application. These models have the same area for each story; thus, the variations are given only on the building plan. Time-history earthquake loads are used in this study. The north-south part of the building is vertically burdened, and in the east-west part, the El Centro and Kobe loads are used; thus, effects that are close to real conditions will be known. The El Centro earthquake has an increased acceleration: $210.1 \mathrm{~cm} / \mathrm{s} 2$ in the eastwest direction, $314.7 \mathrm{~cm} / \mathrm{s}$ in the north-south direction, and $206.3 \mathrm{~cm} / \mathrm{s} 2$ in the vertical direction. The Kobe earthquake has a much greater acceleration than the El Centro earthquake: $617.1 \mathrm{~cm} / \mathrm{s} 2$ in the east-west direction, $817.8 \mathrm{~cm} / \mathrm{s} 2$ in the north-south direction, and $332.2 \mathrm{~cm} / \mathrm{s} 2$ in the vertical direction. The loading is done by providing a three-way earthquake model in the cube-shaped, L-shaped, and U-shaped building models vertical irregularity; then, the properties shown by each structural building model can be seen directly.

\section{RESULTS AND DISCUSSIONS}

\subsection{Building Stiffness}

Stiffness is modeled by providing load in stages to show the damage in certain calculations. Figure 4 illustrates the relationship between step calculations and the story drift produced by each story. Each story from the modeling method showed different results. For each model tested, a significant difference existed in the stiffness of the first story of each model. Figure 5 is the stiffness result for each model, and Figure 5 (a) depicts the stiffness produced on each story, while Figure 5 (b) depicts the highest stiffness obtained. The U-shaped building model showed the greatest stiffness value, i.e., $2125 \mathrm{kN}$, compared with other models. That stiffness value is $7.43 \%$ higher than that of the cube-shaped building model and 3.01\% higher than that of the L-shaped building model. This phenomenon occurred because the U-shaped building model had a greater cross section in the $\mathrm{X}$-direction.

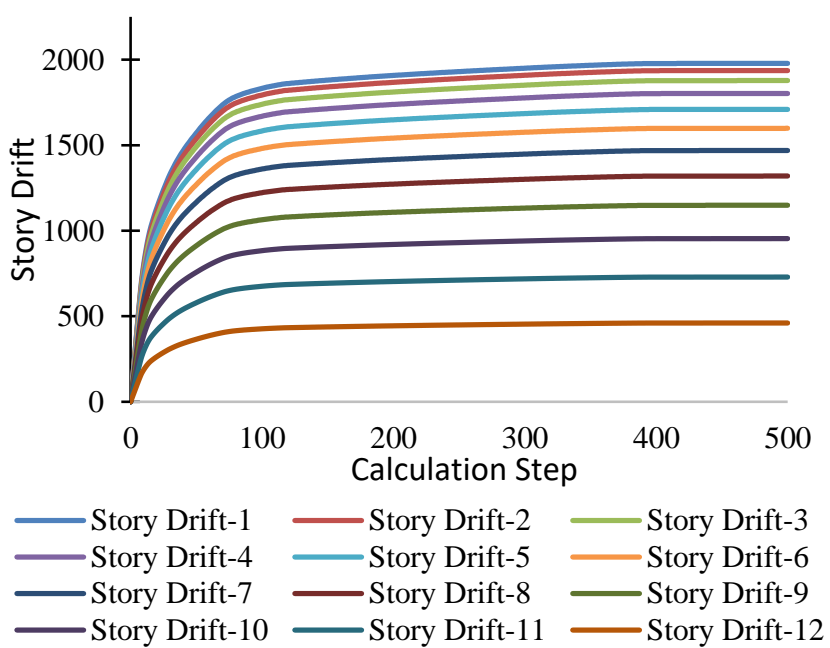

(a)
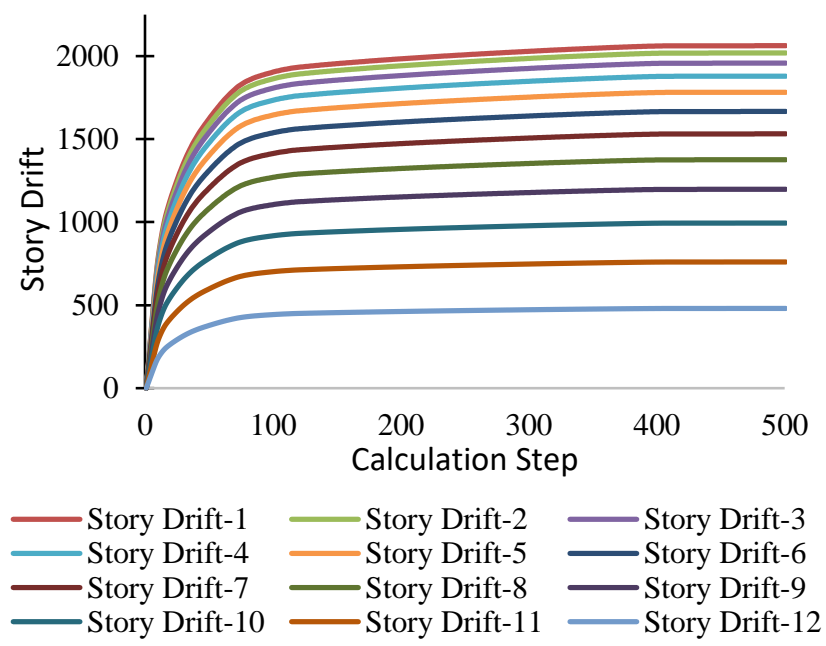

(b)

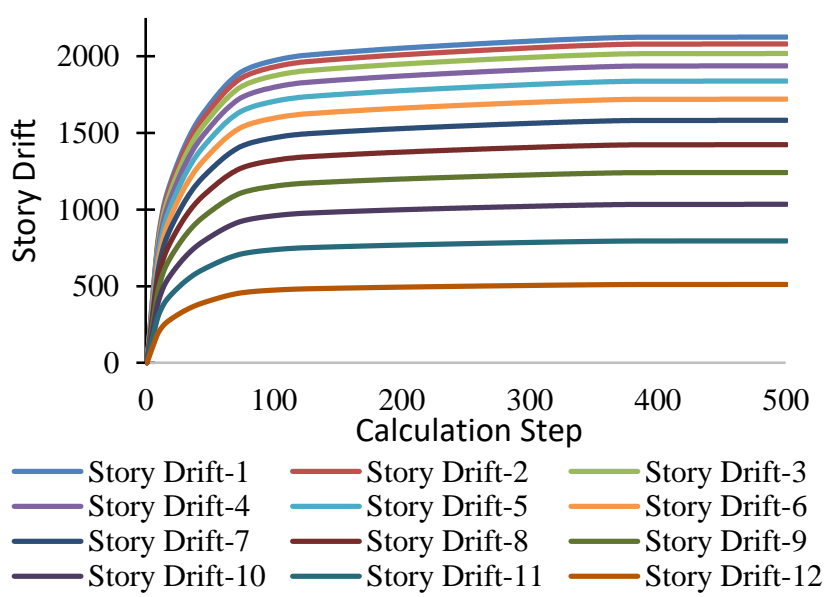

(c)

Figure 4. The relationship between story drift and step calculation in terms of stiffness for the (a) cube-shaped,

(b) L-shaped, and (c) U-shaped building models 


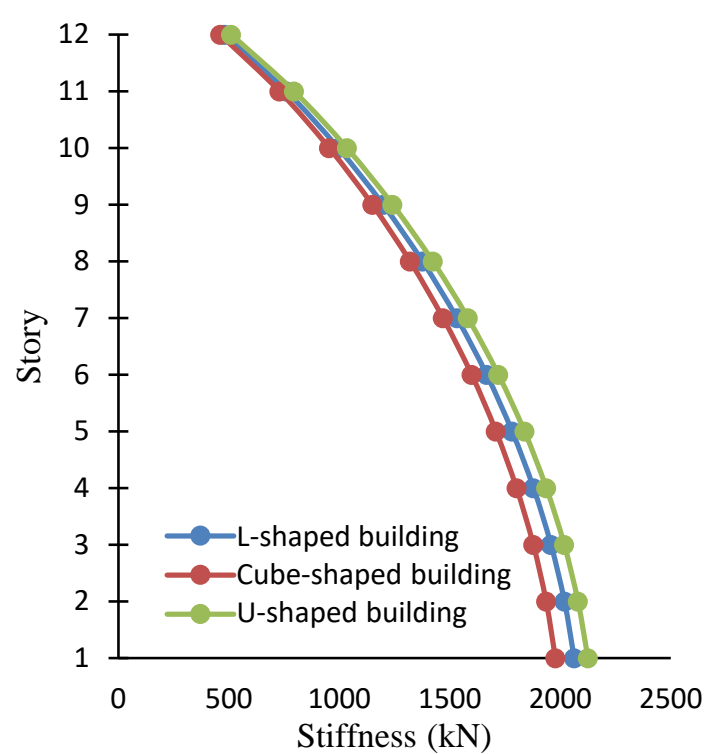

(a)

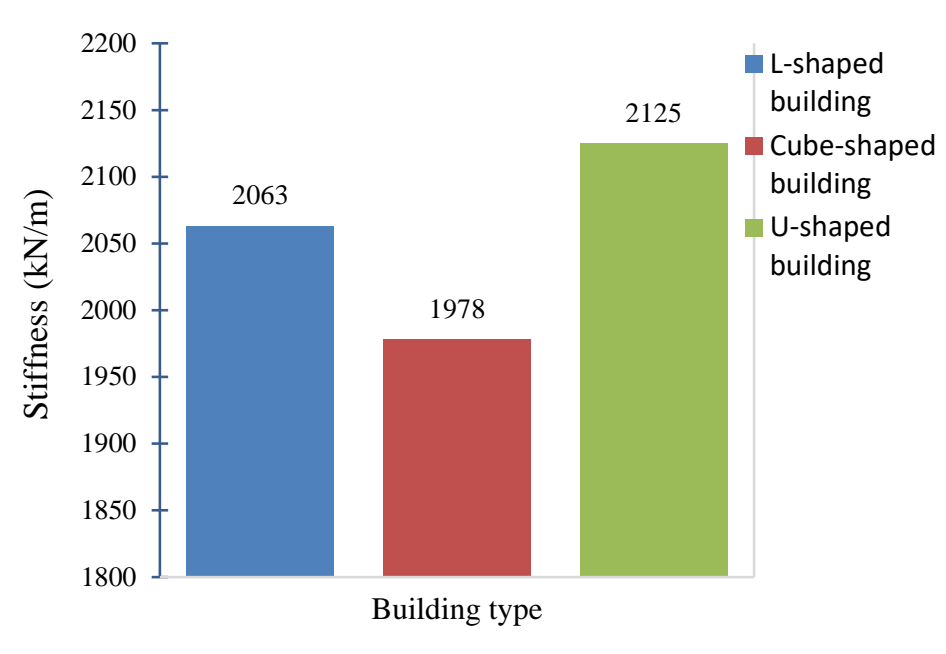

(b)

Figure 5. (a) Stiffness values on each story; (b) the value of maximum stiffness

\subsection{Displacement Value}

Displacement is one of the requirements used to know building security and building stiffness. The displacement that resulted from the force received from the structure is calculated based on a certain displacement from the control point, called the displacement target, as the maximum displacement that can occur in the structure at the time the planned earthquake occurs. The displacement provides information about the maximum natural distance by the structure model; therefore, the smallest displacement can be known. The results of the study show the displacement value of the top story of the building due to the force exerted on the ground by the existence of the earthquake; the displacement will indicate the maximum value of displacement experienced by the model.

The most significant displacements that occurred from the three models after being given the same earthquake force are as follows: For the El Centro earthquake, in the X-direction, the cube-shaped model exhibited the most significant displacement $(15.85 \mathrm{~cm})$, while the U-shaped model exhibited the smallest displacement (15.15 $\mathrm{cm})$. Meanwhile, in the Y-direction, the U-shaped model exhibited the most significant displacement $(19.5 \mathrm{~cm})$, while the cube-shaped model showed the smallest displacement (18.97 $\mathrm{cm}$ ), as shown in Table 2. Table 2, which presents the displacement due to the Kobe earthquake, shows a significant difference in the displacement due to the Kobe earthquake from that due to the El Centro earthquake; the maximum displacement due to the Kobe earthquake is higher than that due to the El Centro earthquake. For the Kobe earthquake, the L-shaped model produced the most significant displacement in the X-direction, which was $23.81 \mathrm{~cm}$, and the Ushaped model produced the most significant displacement in the Y-direction, which was 36 $\mathrm{cm}$.

The results of this study show the value of the top story displacement of the building and the base shear forces generated by the earthquake force applied to each model. The same earthquake force was applied to the three models, and the Ushaped model exhibited the most significant displacement in the X-direction $(15.98 \mathrm{~cm})$, with a base shear force of $1825 \mathrm{kN}$, and the L-shaped model exhibited the smallest displacement (15.72 $\mathrm{cm})$, with a base shear force of $1934 \mathrm{kN}$. As for the Y-direction, the U-shaped model exhibited the most significant displacement $(20.17 \mathrm{~cm})$, with the base shear force being $1974 \mathrm{kN}$, and the cubeshaped model exhibited the smallest 
displacement $(18.97 \mathrm{~cm})$, with the base shear force being $2020 \mathrm{kN}$.

Modeling using the Kobe earthquake as a force on the ground of the structure provided a large enough displacement and force, which had a significant impact on each structural model; the force of the Kobe earthquake resulted in a greater displacement than that of the El Centro earthquake. The maximum displacement due to earthquake in the cube-shaped model in the Xdirection was $23.4 \mathrm{~cm}$, and the maximum base shear force was $2877 \mathrm{kN}$; in the Y-direction, the displacement was 35.64, and the maximum base shear force was $2774 \mathrm{kN}$. The L-shaped model produced a displacement in the X-direction of $23.81 \mathrm{~cm}$ and a maximum base shear force of 3062; and in the Y-direction, a displacement of $35.44 \mathrm{~cm}$ and a maximum base shear force of 2937 $\mathrm{kN}$. The U-shaped model produced a displacement in the X-direction of $23.71 \mathrm{~cm}$ and a maximum base shear force of $2897 \mathrm{kN}$; and in the Y-direction, a displacement of $35.87 \mathrm{~cm}$ and a maximum base shear force of $2802 \mathrm{kN}$. Figure 6 to 8 illustrate the relationship between displacement and vibration time for each type of model. The deviation was from the $\mathrm{X}$ and $\mathrm{Y}$ directions of the El Centro and Kobe earthquakes.

Table 2. The result of displacement and base shear force for the El Centro and Kobe earthquake models

\begin{tabular}{llllll}
\hline Building & Direction & $\begin{array}{l}\text { Maximum } \\
\text { Displacement }(\mathrm{cm}) \\
\text { El Centro }\end{array}$ & $\begin{array}{l}\text { Maximum Base } \\
\text { Shear Force }(\mathrm{kN}) \\
\text { El Centro }\end{array}$ & $\begin{array}{l}\text { Maximum } \\
\text { Displacement }(\mathrm{cm}) \\
\text { Kobe }\end{array}$ & $\begin{array}{l}\text { Maximum Base } \\
\text { Shear Force }(\mathrm{kN}) \\
\text { Kobe }\end{array}$ \\
\hline Cube-shaped & $\mathrm{X}$ & 15.85 & 1869 & 23.40 & 2877 \\
model & $\mathrm{Y}$ & 18.97 & 2020 & 35.64 & 2774 \\
L-shaped & $\mathrm{X}$ & 15.72 & 1934 & 23.81 & 3062 \\
model & $\mathrm{Y}$ & 19.20 & 2126 & 35.44 & 2937 \\
U-shaped & $\mathrm{X}$ & 15.98 & 1825 & 23.71 & 2897 \\
model & $\mathrm{Y}$ & 20.17 & 1974 & 35.87 & 2802 \\
\hline
\end{tabular}

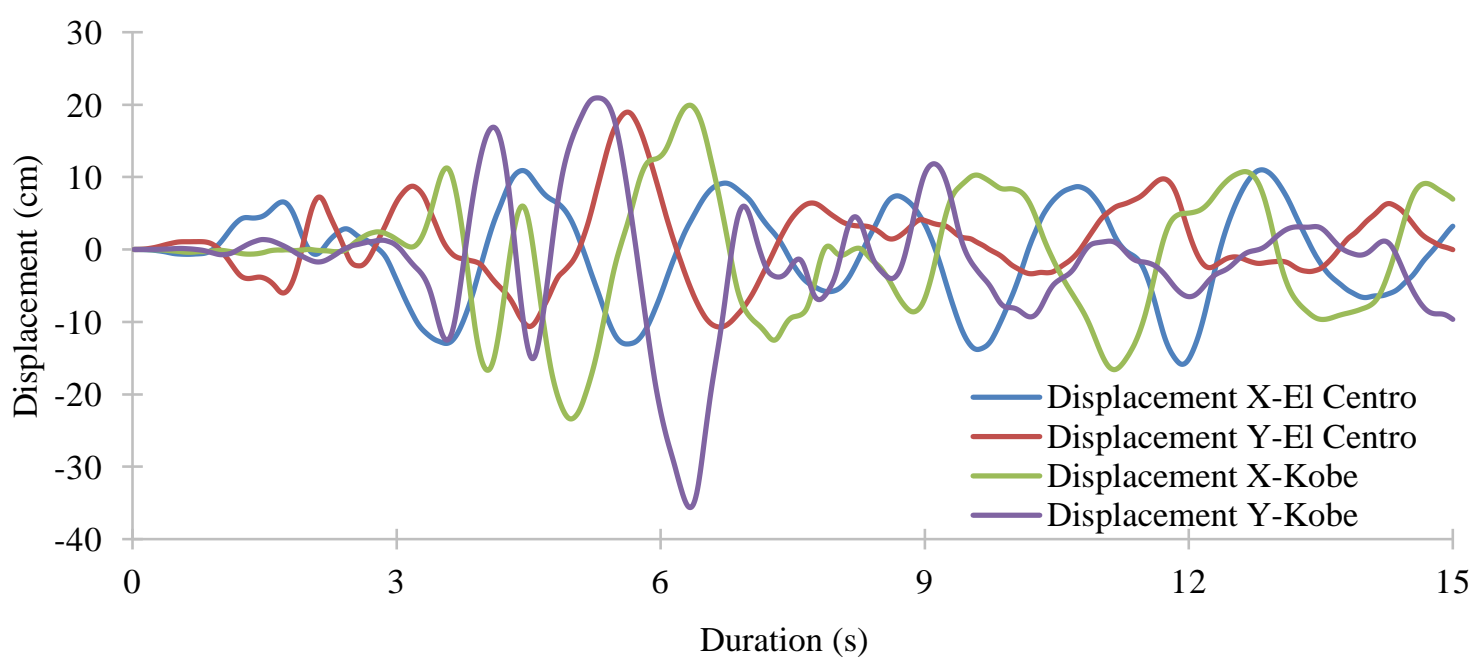

Figure 6. Relationship between the earthquake displacement and earthquake vibration time of the cube-shaped model 


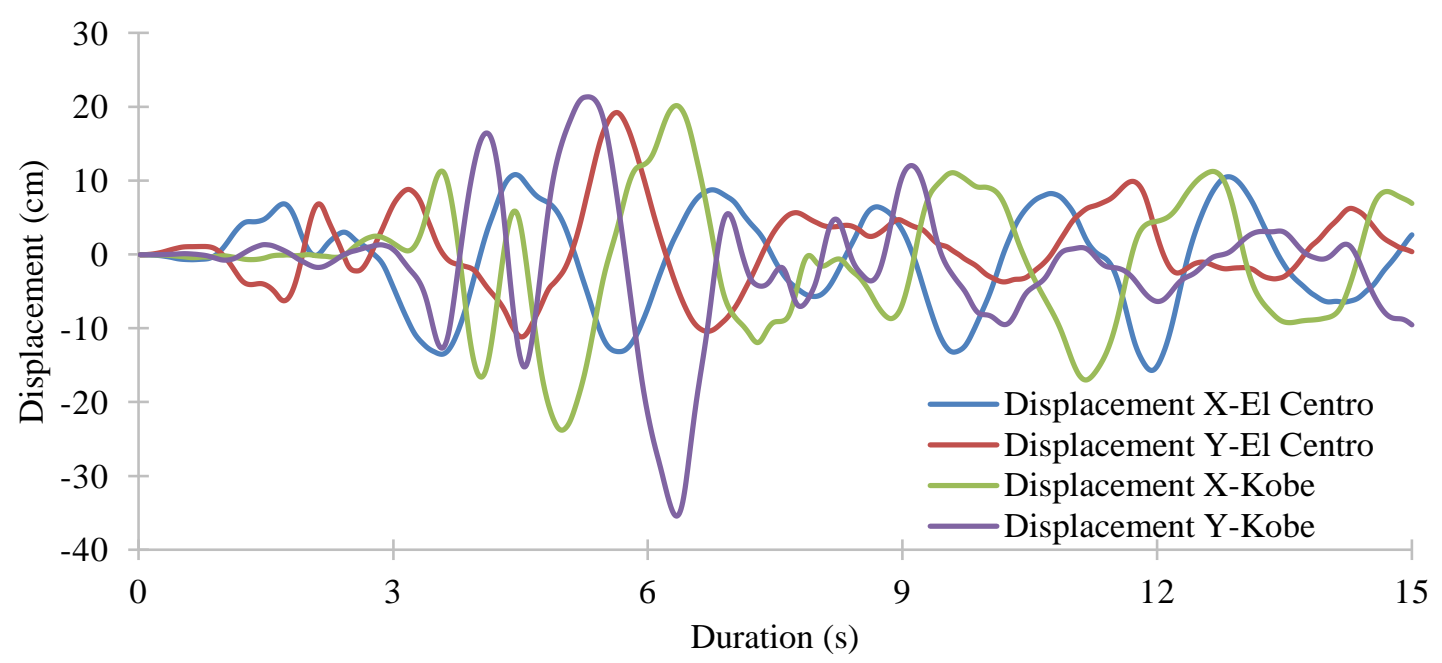

Figure 7. Relationship between the displacement and earthquake vibration time of the L-shaped model

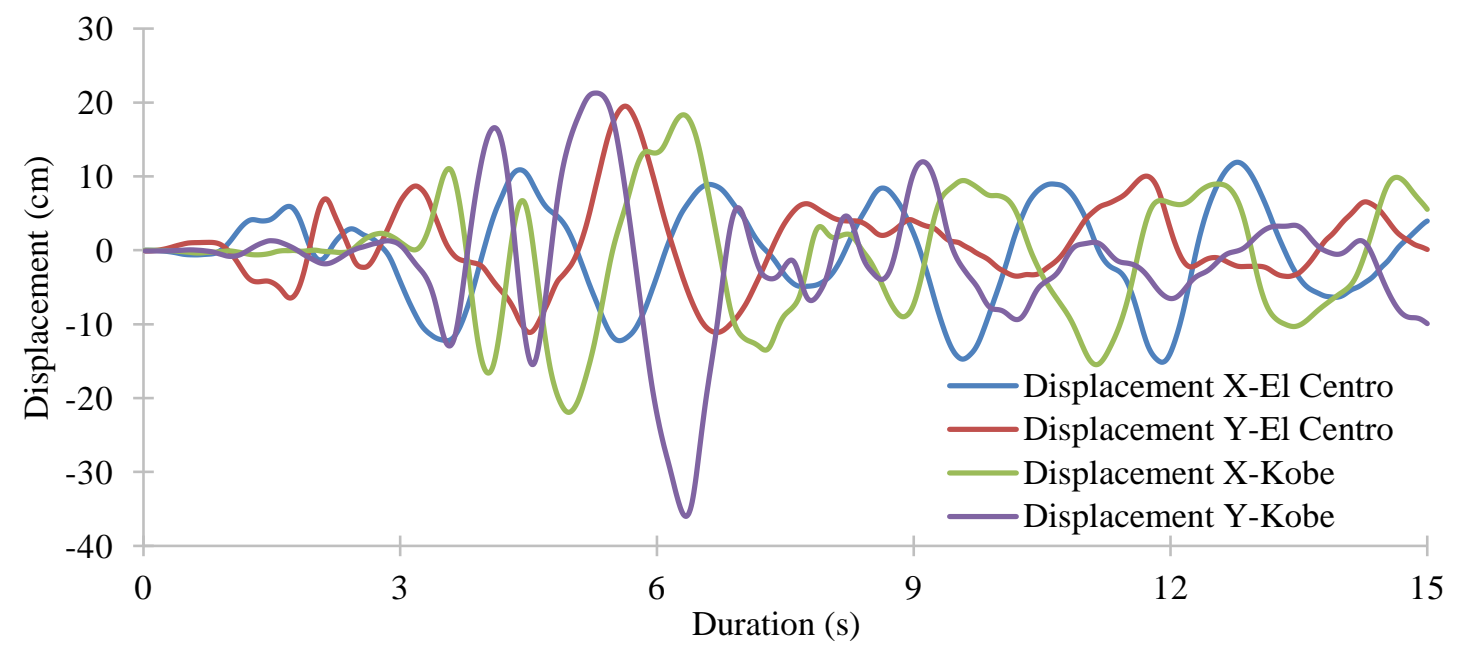

Figure 8. Relationship between the displacement and earthquake vibration time of the U-shaped model

\subsection{Maximum Acceleration}

The acceleration of a structure is influenced by the ratio between the responses that occur in one story and the story below. The smaller the ratio between the stories, the greater the maximum acceleration value that the structure has before the structure is damaged. The relationship of the acceleration value with the number of stories can be seen in Figure 9 to Figure 11. Figure 9 illustrates the relationship between the maximum acceleration value and the number of stories for square-shaped buildings. Figure 10 illustrates the maximum acceleration relationship for L-shaped buildings, while that for U-shaped buildings can be seen in Figure 11.
The results of the acceleration of each structural model for the El Centro earthquake show that the lowest acceleration values always occur in the middle of the stories, that is, the seventh story for the $\mathrm{X}$-direction and the eighth story for the Ydirection. The highest acceleration value always occurs on the lower stories of each model, that is, the first story for the $\mathrm{X}$-direction and the second story for the Y-direction. For the Kobe earthquake, it can be seen that the greatest acceleration occurs on the first story, with the value of each model not significantly different. The largest acceleration $\left(760.8 \mathrm{~cm} / \mathrm{s}^{2}\right)$ occurs in the first story of the cube-shaped model in the Ydirection, and the smallest acceleration (141.8 $\mathrm{cm} / \mathrm{s}^{2}$ ) occurs in the eighth story of the L-shaped model in the $\mathrm{X}$-direction. 


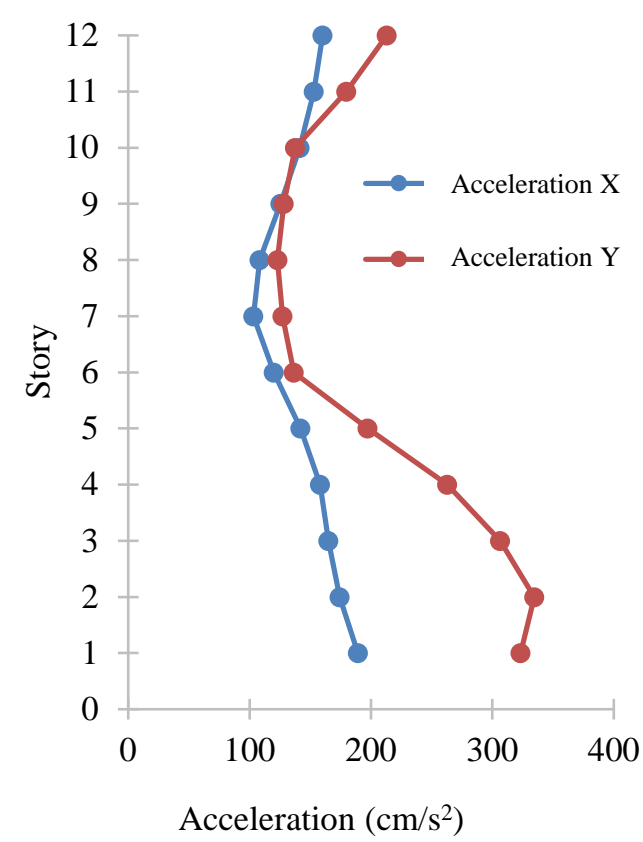

(a)

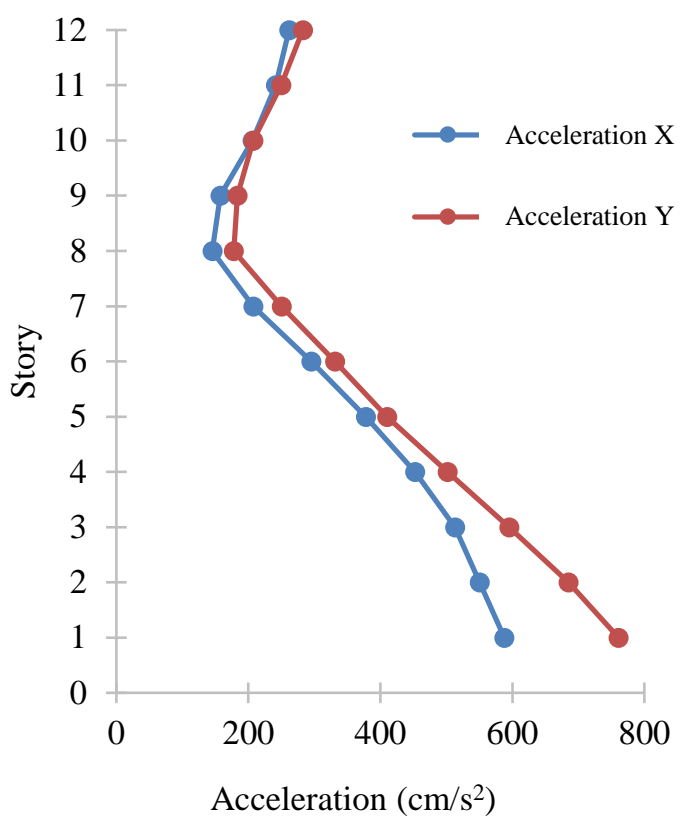

(b)

Figure 9. (a) Acceleration of the cube-shaped model for the El Centro earthquake; (b) Acceleration of the cube-shaped model for the Kobe earthquake

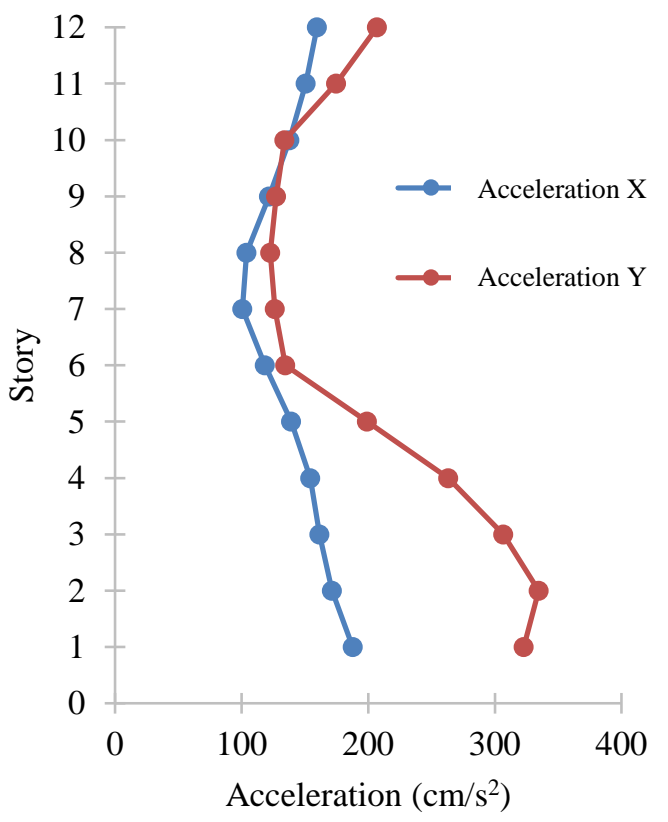

(a)

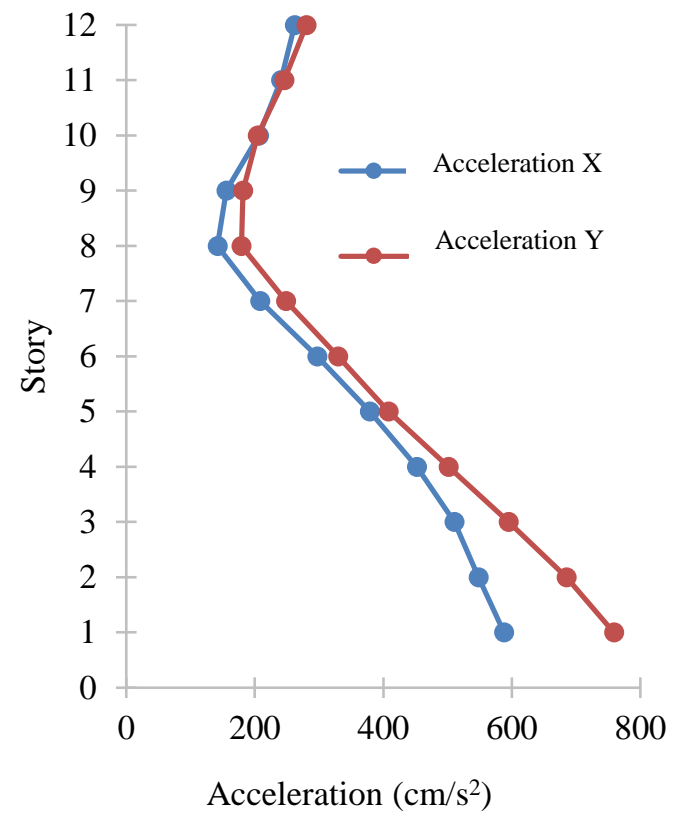

(b)

Figure 10. (a) Acceleration of the L-shaped model for the El Centro earthquake; (b) Acceleration of the L-shaped model L for the Kobe earthquake 


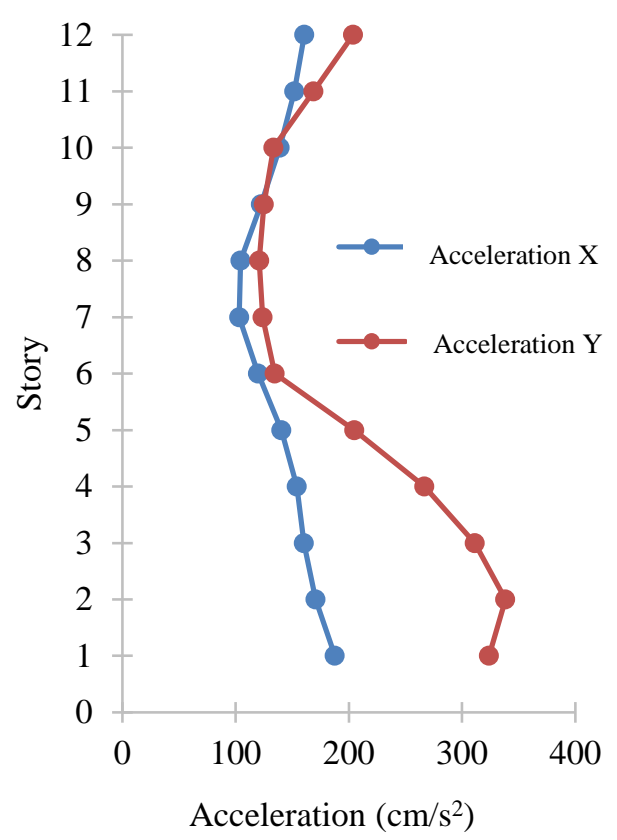

(a)

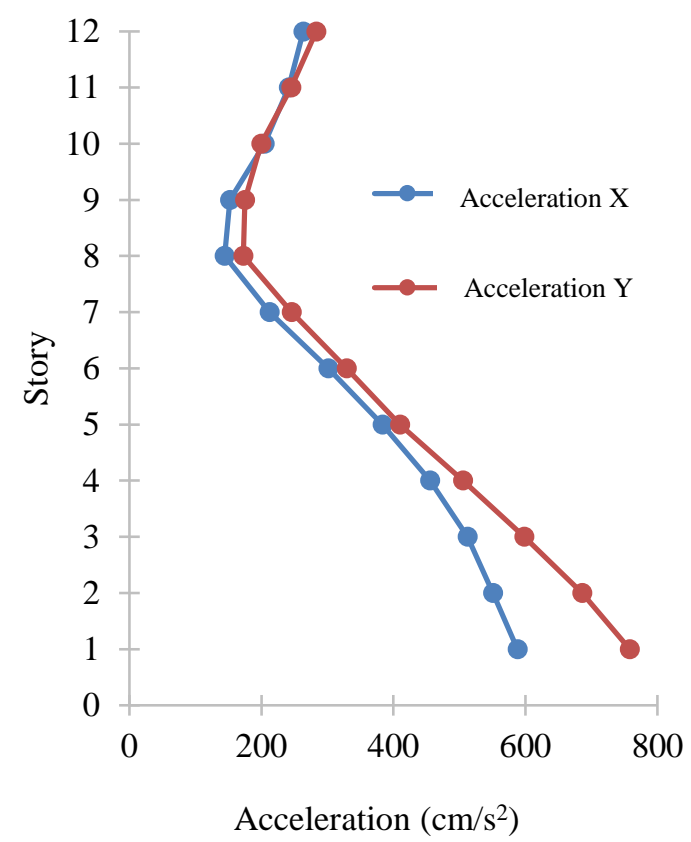

(b)

Figure 11. (a) Acceleration of the U-shaped model for El Centro earthquake; (b) Acceleration of the U-shaped model for Kobe earthquake

\subsection{Hysteretic Energy}

Hysteretic energy is the total energy that occurs in each cycle. The ability of the structure to absorb the energy becomes a basis to determine the structure resistance ability. The trapezoidal method with many piles is used to calculate hysteretic energy based on the total energy area and using numerical integration. The load applied and the lateral displacement of the structure in the L-shaped model, the cube-shaped model, and the U-shaped model can be seen in Table 3. In Figure 12, structural modeling with the El Centro earthquake shows that the U-shaped model has the highest hysteretic energy value of $60.77 \mathrm{kNm}$, followed by the L-shaped model structure, which has a value of $57.02 \mathrm{kNm}$, and the cube-shaped model has the smallest hysteretic energy, 57.02 $\mathrm{kNm}$. The differences owned by each structural model are quite large due to the burden not being well distributed throughout the model.
For the Kobe earthquake, the results of the modeling with earthquake load show that the Lshaped model exhibited the greatest hysteretic energy value, $110.54 \mathrm{kNm}$. The greater the hysteretic energy that occurs in the structural model, the lower the structure collapse rate and the greater the structure rigidity; moreover, the structure would have a large lateral displacement; conversely, the smaller the hysteretic energy value, the higher the structural collapse rate and the lower the stiffness. Differences exist in the hysteretic energy produced by the models with the El Centro and Kobe earthquake loadings. It can be seen that in the El Centro earthquake loading, the L-shaped model generated the largest hysteretic energy value, while in the Kobe earthquake, the U-shaped model generated the largest hysteretic energy value. Figure 12 depicts a comparison between the hysteretic energy values produced as a result of the El Centro and Kobe earthquake forces 
Table 3 Load and lateral displacement of building

\begin{tabular}{lllll}
\hline \multirow{2}{*}{ Objects } & \multicolumn{3}{c}{ El Centro 1940 } & Kobe 2015 \\
\cline { 2 - 5 } & $\begin{array}{l}\text { Loading } \\
(\mathrm{kN})\end{array}$ & $\begin{array}{l}\text { Lateral Displacement } \\
(\mathrm{m})\end{array}$ & $\begin{array}{l}\text { Loading } \\
(\mathrm{kN})\end{array}$ & $\begin{array}{l}\text { Lateral Displacement } \\
(\mathrm{m})\end{array}$ \\
\hline L-shaped model & 311.90 & 0.19 & 311.90 & 0.35 \\
Cube-shaped model & 300.60 & 0.19 & 300.60 & 0.36 \\
U-shaped model & 301.30 & 0.20 & 301.30 & 0.36 \\
\hline
\end{tabular}

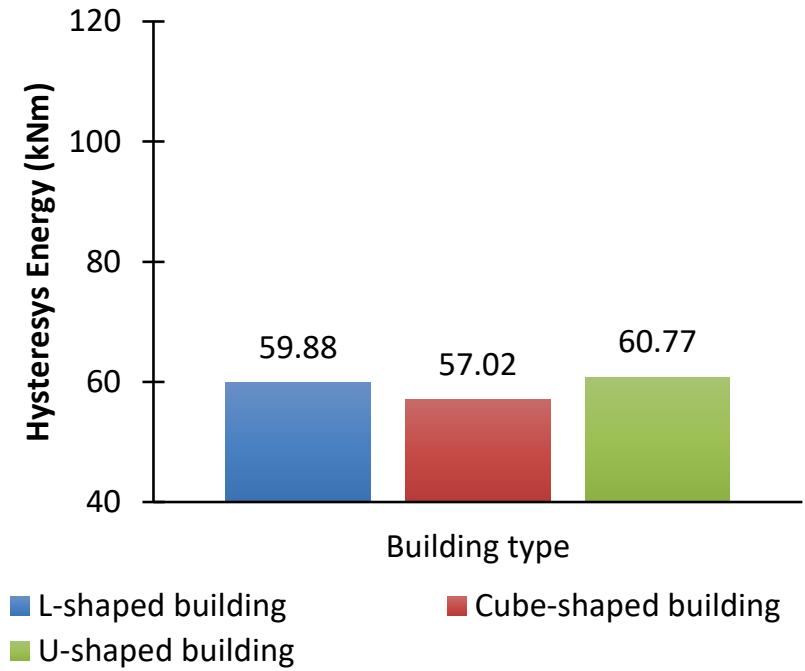

(a)

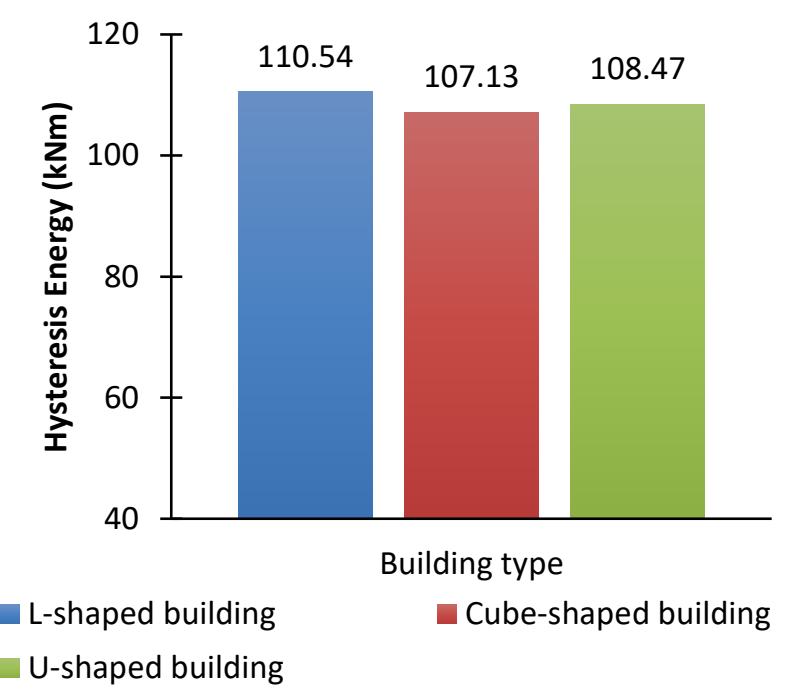

(b)

Figure 12. Comparison of hysteretic energy values of the L-shaped, cube-shaped, and U-shaped models for (a) the El Centro earthquake and (b) the Kobe earthquake

\section{CONCLUSIONS}

Based on the modeling of horizontal cross section variations using the STERA 3D software, the Lshaped model was found to have the highest stiffness value of $2063 \mathrm{kN}$; the cube-shaped model, a stiffness value of $1978 \mathrm{kN}$; and the Ushaped model, a stiffness value of $2125 \mathrm{kN}$. Considering the El Centro earthquake, the Ushaped model produced the largest displacement of $20.17 \mathrm{~cm}$, while for the Kobe earthquake, the Ushaped model produced the largest displacement of $35.87 \mathrm{~cm}$. The relationship between the force and displacement that occurred shows that for the El Centro earthquake, the L-shaped model exhibited the greatest stiffness in terms of the base shear force shown, which is a lateral deviation value of $19.20 \mathrm{~cm}$ and a load of $2126 \mathrm{kN}$, whereas for the Kobe earthquake, the L-shaped model exhibited stiffness by showing a lateral deviation of $23.81 \mathrm{~cm}$ and a load of $3062 \mathrm{kN}$.
Moreover, the U-shaped model structure generated the greatest acceleration $\left(338.3 \mathrm{~cm} / \mathrm{s}^{2}\right)$ that occurred in the El Centro earthquake, and in the Kobe earthquake, the cube-shaped model structure generated the greatest acceleration $\left(760.8 \mathrm{~cm} / \mathrm{s}^{2}\right)$. In addition, for the El Centro earthquake, the cube-shaped model produced the smallest hysteretic energy (57023820 Nmm), while for the Kobe earthquake, the cube-shaped model also produced the smallest hysteretic energy (107133840 Nmm). The cube-shaped model had the most stable structure because it produced a relatively small lateral deviation in the El Centro earthquake, which is $15.85 \mathrm{~cm}$ with a loading of $1869 \mathrm{kN}$ in the $\mathrm{X}$-direction and 18.97 with the loading of 2020 in the Y-direction. Meanwhile, in the Kobe earthquake, the deviation was $23.4 \mathrm{~cm}$ with a loading of $2877 \mathrm{kN}$ in the Xdirection and $35.64 \mathrm{~cm}$ with a loading of $2774 \mathrm{kN}$ 
in the Y-direction. The stiffness value exhibited by the structural model is $1978 \mathrm{kN}$, and the hysteretic energy value is $57.02 \mathrm{kNm}$ in the $\mathrm{El}$ Centro earthquake and $107.13 \mathrm{kNm}$ in the Kobe earthquake.

\section{DISCLAIMER}

The authors declare no conflict of interest.

\section{REFERENCES}

Brunesi, E. Casagrande, L. \& Nascimbene, R., 2016. Seismic Analysis of High-Rise Mega-Braced Frame-Core Buildings. Engineering Structures, Vol. 115, pp. 1-17.

Cornelis, R. B., \& Umbu, T. B., 2014. Analisis Perbandingan Gaya Geser Tingkat, Gaya Geser Dasar, Perpindahan Tingkat, dan Simpangan Antar Tingkat Akibat Beban Gempa Berdasarkan Peraturan Gempa SNI 1726-2002 dan SNI 17262012. Jurnal Teknik Sipil, Vol. 3 No. 2, pp. 205216.

Federal Emergency Management Agency, 2011. FEMA 426 - Reference Manual to Mitigate Potential Terrorist Attacks Against Buildings. Washington, D.C: The U.S. Department of Homeland Security (DHS).

Kapojos, C. G., Tamuntuan, G., \& Pasau, G., 2015. Analisis Percepatan Tanah Maksimum dengann Menggunakan Rumus Esteva dan Donovan (Studi Kasus pada Semenanjung Utara Pulau Sulawesi). Jurnal Ilmiah Vol. 15 No. 2, pp. 99-104.

Li, S., Yu, B., Gao, M., \& Zhaia, C., 2019. Optimum Seismic Design of Multi-Story Buildings for Increasing Collapse Resistant Capacity. Soil Dynamics and Earthquake Engineering, Vol. 116, pp. 495-510.

Louzai, A., \& Abed, A., 2014. Evaluation of the Seismic Behavior Factor of Reinforced Concrete
Frame Structures Based on Comparative Analysis Between Non-Linear Static Pushover and Incremental Dynamic Analyses. Bulletin Earthquake Engineering, pp. 1773-1793.

Lu, X., Xie, L., Guan, H., Huang, Y., \& Lu, X. ,2015. A shear wall element for nonlinear seismic analysis of super-tall buildings using Open Sees. Finite Elements in Analysis and Design, Vol. 98, pp. 14-25.

Majore, B. O, 2015. Studi Perbandingan Respons Dinamik Bangunan Bertingkat Banyak dengan Variasi Tata Letak Dinding Geser. Jurnal Sipil Statik, Vol. 3 No. 6, pp. 435-446.

Massinai, M. M., Massinai, K., Virman, Lantu, \& Muhammad, F. I., 2016. Analisis Percepatan Tanah Maksimum, Kecepatan Tanah Maksimum dan MMI di Wilayah Sulawesi Utara. Jakarta, Seminar Nasional Fisika 2016.

Pavel, F., 2018. Simplified Seismic Collapse Evaluation of Code Conforming Reinforced Concrete Structures in Bucharest, Romania. Iranian Journal of Science and Technology, Transactions of Civil Engineering, pp. 1-6.

Saito, T., 2016. Response of High-Rise Buildings under Long Period Earthquake Ground Motions. International Journal of Structural and Civil Engineering Research, Vol. 5 No. 4, pp. 308-314.

Weningtyas, E. R., 2017. Studi Numberik Sambungan Balok Kolom Beton Bertulang Pracetak Eksterior dengan Variasi Penampang Balok Menggunakan Beban Statik, Yogyakarta: Undergraduate Thesis Report. Department of Civil Engineering, Universitas Muhammadiyah Yogyakarta 
[This page is intentionally left blank] 